\title{
ORGANIZACJA I FUNKCJONOWANIE DIECEZJI CHEŁMSKIEJ W ŚWIETLE RELACJI „AD LIMINA” Z 1594 R.
}

Głównym celem artykułu jest ocena wiarygodności oraz krytyka wartości źródłowej pierwszej relacji o stanie diecezji chełmskiej z 1594 r. w odniesieniu do stanu organizacyjnego diecezji w końcu XVI wieku. Dla wiedzy o sytuacji diecezji chełmskiej jest ona o tyle istotna, że w końcu XVI wieku, a dokładnie 7 kwietnia 1597 r., w pożarze archiwum kurii biskupiej w Krasnymstawie spłonęły akta konsystorza krasnostawskiego, a także akta biskupie oraz beneficjów zawierające przywileje, dokumenty fundacyjne i erekcyjne kościołów całej diecezji chełmskiej (Bieńkowski, „Działalność organizacyjna biskupa Jana Biskupca” 188, 255). Większość informacji dotyczących funkcjonowania diecezji chełmskiej w XV i XVI wieku jest czerpana ze źródeł pośrednich - głównie odpisów dokumentów zawartych w późniejszych aktach wizytacji czy księgach sądowych konsystorskich i biskupich. Z tego powodu wspomniana relacja, datowana na 1594 r., jak i złożona trzy lata później - w 1597 r., stanowią cenne źródła informacji o diecezji sprzed wspomnianego pożaru archiwum, przy czym należy do nich podchodzić ostrożnie i z pewnym dystansem. Do artykułu została załączona krytyczna edycja źródła w postaci Aneksu ${ }^{1}$.

Dr hab. Bogumil Szady, prof. KUL, Ośrodek Badań nad Geografią Historyczną Kościoła w Polsce, Instytut Historii, Katolicki Uniwersytet Lubelski Jana Pawła II; adres do korespondencji: Al. Racławickie 14, 20-950 Lublin; e-mail: szady@kul.lublin.pl; ORCID: 0000-0003-0059-5596

Niniejszy artykuł chciałbym dedykować pamięci prof. Wiesława Müllera, mojego nauczyciela, który wiele lat poświęcił badaniom nad relacjami polskich biskupów epoki nowożytnej sporządzanymi na potrzeby wizytacji ,ad limina”.

${ }^{1}$ Przy opracowaniu aneksu źródłowego kierowano się instrukcją wydawniczą K. Lepszego (Instrukcja wydawnicza dla źródet historycznych). Mimo że instrukcja zaleca stosowanie skrótów, ze względu na niewielkie rozmiary tekstu większość z nich została w tym wypadku rozwinięta. Zgodnie z zaleceniami instrukcji została zmodernizowana pisownia wielkich i małych liter - pewne trudności sprawiła modyfikacja tytulatury i nazw urzędów: „reverendissimus”, „,dominus”, „nuntius”, 
Potrydenckie relacje biskupów składane do Stolicy Apostolskiej stanowią jedno z podstawowych źródeł dla badań nad dziejami struktur oraz instytucji Kościoła katolickiego w Rzeczypospolitej okresu nowożytnego. Mimo to wykorzystywane są najczęściej jako źródła pomocnicze lub uzupełniające ${ }^{2}$, które - podobnie jak procesy informacyjne biskupów - informują w sposób ogólny o stanie diecezji oraz poszczególnych instytucji kościelnych. Wynika to z faktu, że archiwa kościelne obfitują w bardziej szczegółowe i dokładniejsze protokoły wizytacji kanonicznych. Poza tym dostępność relacji biskupów, które są przechowywane w Archivio Apostolico Vaticano (dawniej: Archivio Segreto Vaticano), jest bardziej ograniczona w stosunku do wizytacji kanonicznych dostępnych w Polsce ${ }^{3}$. Nie dotyczy to rzecz jasna relacji opracowanych i wydanych drukiem. Dodatkowo brak ustalonego kwestionariusza w najstarszych relacjach uniemożliwia wykorzystanie tego źródła do systematycznej i porównawczej analizy sytuacji poszczególnych biskupstw. Większą wartość badawczą przedstawiają dla diecezji wschodnich, które posiadają słabiej zachowane protokoły wizytacji (np. diecezja łucka).

Sprawozdania o stanie diecezji były wykorzystywane przez historyków polskich od początku XX wieku. Podwaliny pod prace z tym źródłem położyli przed II wojną światową najpierw L. Boratyński (Boratyński 27-45), a następnie T. Długosz, który już w 1933 r. zapowiedział duże, 4-tomowe wydawnictwo poświęcone edycji relacji biskupów polskich od 1585 do 1800 roku. Swój projekt osadził w szerokim kontekście europejskim i oparł na pracy biskupa J. Schmidlina z lat 1908-1910, który uwzględnił relacje z 11 polskich diecezji, w tym diecezji chełmskiej (Długosz, „Biskupia «visitatio liminum»" 173, 205; Schmidlin passim). Sam Długosz opracował

„cancellarius”, „episcopus”. Odwołano się tutaj do instrukcji dla opracowania źródeł średniowiecznych z 1925 r., która nakazuje stosowanie wielkich liter w tytułach osób tylko w alokucjach (Instrukcja wydawnicza dla średniowiecznych źródeł historycznych, A.I.3.d). Wyjątkiem było stosowanie wielkich liter w odniesieniu do tytulatury papieskiej, np. „Sanctissimo Domino Apostolico”, „Sactitatis Suae". Ze względu na niewielką liczbę nazw osobowych i miejscowych występujących w relacji oraz ich omówienie w tekście artykułu zrezygnowano z wprowadzania do edycji przypisów rzeczowych. $\mathrm{W}$ przypisach redakcyjnych pojawiają się natomiast uwagi i wątpliwości dotyczące pisowni oraz odczytu tekstu. Znalazły się w nich także wszystkie noty marginalne dopisane drugą ręką. W edycji zachowano podkreślenia występujące w rękopisie - można przypuszczać, że podobnie jak noty marginalne były dziełem urzędnika kurii papieskiej przygotowującego relację do rozpatrzenia.

Serdecznie dziękuję Urszuli Zacharze-Związek za modernizację interpunkcji, korektę językową oraz wskazówki edytorskie.

${ }^{2} \mathrm{~W}$ takim ujęciu relacje biskupów zostały potraktowane chociażby w podręczniku H. Wyczawskiego (260).

${ }^{3} \mathrm{~W}$ sposób znaczący dostępność tych źródeł poprawiła akcja mikrofilmowania relacji biskupów polskich przeprowadzona w latach 60. XX wieku przez zespół badawczy z Katolickiego Uniwersytetu Lubelskiego (L. Bieńkowski, W. Müller), kierowany przez J. Kłoczowskiego (258-259). 
i wydał relacje arcybiskupów lwowskich z lat 1595-1794 (Relacje arcybiskupów lwowskich 1595-1794; „Biskupia “visitatio liminum»”), zaś materiał opracowany dla diecezji: smoleńskiej, inflanckiej, kijowskiej, kamienieckiej oraz unickiej metropolii kijowskiej, który już był przygotowany do druku, niestety zaginął w czasie wojny (Kłoczowski 259-260). W okresie powojennym rozwinęły się systematyczne prace nad kolejnymi edycjami oraz prowadzone były badania oparte na protokołach relacji ,ad limina”. Nie przybrały one jednak nigdy formuły jednolitego i opartego na tych samych zasadach edytorskich projektu obejmującego wszystkie diecezje dawnej Rzeczypospolitej należące do metropolii gnieźnieńskiej i lwowskiej. Największe zasługi położyli w tym zakresie W. Wójcik (131-179), W. Müller (Relacje o stanie diecezji krakowskiej), A. Szorc (201-239) oraz P. Rabikauskas (Relationes status dioecesium in Magno Ducatu Lituaniae), a w ostatnim czasie J. Kopiec (Relacje). Mimo znaczącego postępu badań nad relacjami, ciągle aktualny pozostaje postulat wydania protokołów dotyczących najstarszych polskich diecezji (m.in. gnieźnieńskiej, poznańskiej, płockiej).

Przedstawiany poniżej w Aneksie źródłowym raport o stanie diecezji chełmskiej jest jedną z dwóch najstarszych zachowanych relacji przesłanych przez polskich biskupów do Stolicy Apostolskiej po soborze trydenckim. W tym samym roku zostało sporządzone obszerne sprawozdanie o stanie diecezji włocławskiej przez biskupa Hieronima Rozrażewskiego. Wiadomo, że wcześniej, w 1592 r., w imieniu biskupa włocławskiego wizytację w Rzymie odbył jego pełnomocnik Franciszek Laski (właśc. Łącki), archidiakon pomorski, ale nie zachował się jej protokół (Przygodzki 312-313; Długosz, „Biskupia «visitatio liminum»” 199). Podobnie nie zachowały się ślady wizytacji złożonej przez Jana Herbesta, kanonika katedralnego we Lwowie i pełnomocnika arcybiskupa Jana Dymitra Solikowskiego (Długosz, „Biskupia «visitatio liminum»" 209). Długosz oszacował, że biskupi chełmscy odbyli w sumie 25 wizytacji ,ad limina” w okresie nowożytnym, tj. od wydania przez papieża Sykstusa V w 1585 r. bulli „Romanus Pontifex”, która zobowiązywała biskupów do takiej wizytacji, do końca wieku XVIII (199). Wyższą liczbę (27) podał Wójcik - poza drobną korektą w chronologii niektórych relacji, uzupełnił zestawienie Długosza o dwie wizytacje ,ad limina” z lat 1608 i 1614 (Wójcik 163-164).

Aż do pierwszej połowy XVIII wieku nie było ustalonego formularza, który określałby zakres rzeczowy oraz strukturę przygotowania sprawozdania o stanie diecezji na potrzeby wizytacji ,ad limina”. Dopiero w 1725 roku została wydana dość szczegółowa instrukcja ułożona przez Prospera Lambertiniego, sekretarza Kongregacji Soboru, która nawiązywała do struktury procesów informacyjnych.

\footnotetext{
${ }^{4}$ Do 1962 r. zmikrofilmowano 22 relacje chełmskie (Kłoczowski 261).
} 
Można w niej wyróżnić dwie główne części: pierwsza dotyczyła stanu diecezji i jej głównych instytucji (stan materialny diecezji, w tym opis granic, liczba mieszkańców, kościół katedralny i kapituła katedralna, kościoły kolegiackie i parafialne, klasztory, seminarium, szpitale, bractwa i miejsca święte, wierni), zaś druga odnosiła się do stanu duchowieństwa (biskup, duchowieństwo diecezjalne świeckie, kler zakonny i miniszki). Całość zagadnień, pogrupowaną w osiem paragrafów, miał uzupełniać paragraf 9 dotyczący próśb i petycji kierowanych przez biskupów do Stolicy Apostolskiej, których celem była poprawa kondycji diecezji (Długosz, „Biskupia «visitatio liminum»” 273-275; Wójcik 157-158).

Jak zostało wyżej wspomniane, relacje biskupie długo nie miały jednolitej formy, zaś według najbardziej generalnej charakterystyki zaproponowanej przez Wójcika można je podzielić na sporządzone w formie listów („stylus epistolaris”) lub wyciągów z wizytacji kanonicznych („visitationis compendium”) (Wójcik 172-173). Relacja biskupa Stanisława Gomolińskiego, a właściwie relacja o stanie diecezji chełmskiej pod jego rządami z 1594 r., ma formę pośrednią. Mimo że dokument nie zawiera otwierającej formuły grzecznościowej określającej adresata ani nie jest podpisany, ma dość czytelną konwencję i zdradza intencje oraz motywy powstania tego dokumentu. Można powiedzieć, że cały tekst stanowi rozwinięte uzasadnienie do szeregu postulatów i próśb kierowanych do Stolicy Apostolskiej. Bardzo często pojawia się tryb warunkowy, uzależniający poprawę sytuacji w diecezji od decyzji i rozstrzygnięć papieża w konkretnych sprawach. Postulaty biskupa nie zostały zebrane w jednym miejscu na końcu tekstu, jak zalecała wydana później instrukcja, ale pojawiają się w wielu miejscach w postaci bezpośredniej lub nieco zawoalowanej. W swojej formie odpowiada charakterystyce relacji z niewielkich diecezji kresowych. Nie jest to list skierowany bezpośrednio przez biskupa Gomolińskiego do papieża, ale jest napisany o biskupie chełmskim w trzeciej osobie. Według Wójcika: „Bywało i tak, że dopiero w Rzymie pisał prokurator, kanonik kapituły sprawozdanie w trzeciej osobie o biskupie i dodawał załącznik" (170172). Niestety nie udało się ustalić tożsamości owego pełnomocnika wizytującego Stolicę Apostolską w zastępstwie Gomolińskiego. Wiadomo tylko, że był to jeden z kanoników katedralnych. Nie jest także znana dokładna data sporządzenia relacji. Sam dokument nie jest datowany, zaś rok „1594” pojawia się w prawym górnym rogu pierwszej strony, dopisany ołówkiem. Datę tę uwiarygadnia fragment relacji wspominający synod diecezjalny odbyty rok wcześniej (Bieńkowski, „Nieznany synod diecezji chełmskiej”) oraz wzmianka w kolejnej relacji biskupa Gomolińskiego złożonej za pośrednictwem kanonika Andrzeja w 1597 r. („Ante triennium miserat reverendissimus dominus episcopus Chelmensis unum ex canonicis cum sufficienti informatione ad Sedem Apostolicam”) (AAV. Congr. Concilio, Relat. Dioec. 217, 
k. 477)5. Potwierdzają ją także istniejące zestawienia wszystkich relacji ,ad limina” (Boratyński 29; Długosz, „Biskupia «visitatio liminum»” 224-225; Wójcik 163).

Próbując dotrzeć do okoliczności, które mogły wpłynąć na kształt relacji biskupa Gomolińskiego, warto wspomnieć o generalnym stosunku polskich biskupów, w tym biskupa chełmskiego, do reform soboru trydenckiego, których pokłosiem i jednym z ważniejszych przejawów był obowiązek wizytacji ,,ad limina”. Gomoliński swoją karierę kościelną zawdzięczał w znacznym stopniu koneksjom rodzinnym, „Był bowiem «siestrzankiem» biskupa krakowskiego Piotra Myszkowskiego, ciotecznym bratem biskupa kujawskiego Hieronima Rozrażewskiego" (Lepszy 272273). Należał też do nurtu tzw. pozytywnego - używając określenia Stanisława Przygodzkiego - względem dekretów trydenckich i był zwolennikiem, podobnie jak Rozrażewski czy Myszkowski pracy pozytywnej w duchu soborowym. Nie jest przypadkiem, że właśnie relacje ,ad limina” biskupa włocławskiego i chełmskiego należą do najwcześniejszych - relacja Gomolińskiego została złożona zaledwie trzy lata po objęciu przez niego biskupstwa w Chełmie ${ }^{6}$. W tym samym nurcie należy umieszczać arcybiskupa lwowskiego Dymitra Solikowskiego, który dotrzymał obowiązku wizytacji przez pełnomocnika w 1593 r. i 1595 r., choć prosił o jej odroczenie (Relacje arcybiskupów lwowskich 2-3; Przygodzki 306-307).

Rozwój badań nad relacjami oraz porównanie ich treści z innymi materiałami wpłynęły na rosnący sceptycyzm historyków wobec wartości poznawczej tej kategorii źródła. Po pierwszym okresie fascynacji i wysokiej oceny relacji „,ad limina” jako źródła wiedzy o dziejach kościołów lokalnych (J. Schmidlin) przyszedł okres bardziej umiarkowanych albo całkiem krytycznych opinii. Odrębne teksty o charakterze źródłoznawczym przygotował Długosz („Wartość relacji rzymskich” 89-92; „Biskupia «visitatio liminum»” 290-293). Kwestia ta była podejmowana jako wstępna także przy analizie relacji krakowskich (Müller), warmińskich (Szorc) czy $\mathrm{z}$ diecezji wschodnich (Relationes status dioecesium) (Müller, „Diecezja krakowska w relacjach biskupów 7-14; Szorc 236-238; Rabikauskas t. 2, XXXVII-XLI). Wszyscy autorzy podkreślali, że relacji nie można traktować jako obiektywnego dokumentu o charakterze formalno-prawnym. Istotny był cały kontekst oraz okoliczności przygotowania takiego dokumentu. Ich kształt był zdeterminowany przez formę samej wizytacji ,ad limina” jako obowiązku poddanego względem zwierzchnika.

\footnotetext{
${ }^{5}$ Foliacja na podstawie mikrofilmu, Instytut Historii KUL.

${ }^{6}$ Warto przypomnieć, że polscy biskupi składali swoje sprawozdania nieregularnie i prosili papieża wielokrotnie o wydłużenie obowiązkowego terminu wizytacji ,ad limina”. Bulla Sykstusa V nie rozstrzygała jednoznacznie, jak często biskupi z Rzeczypospolitej byli zobowiązani odwiedzać Stolicę Apostolską. Sami biskupi najczęściej poczuwali się do obowiązku składania sprawozdań co cztery lata (Müller, „Diecezja krakowska 14-15; Wójcik 163-166).
} 
Historycy wykorzystujący w swoich badaniach relacje „ad limina” zwracają uwagę na tendencyjny charakter oraz subiektywizm zawartych w nich informacji, który rzutuje w sposób oczywisty na wiarygodność przekazu (Wójcik 173-174). Nieco inne cele bowiem przyświecały Stolicy Apostolskiej, która sformułowała obowiązek takich regularnych sprawozdań, a inne biskupom, którzy starali się przy tej okazji - zdając sobie sprawę z realiów prawnych ustroju Kościoła - zrealizować konkretne zamierzenia. Mogły one wynikać z różnych pobudek - zarówno tych duszpasterskich dotyczących troski o los powierzonej sobie diecezji, jej duchowieństwa i wiernych, jak i czysto partykularnych i prywatnych, za którymi kryło się wyłącznie pragnienie korzyści osobistych czy zdobywania kolejnych szczebli w karierze duchownej. Objęcie w zarząd diecezji w Chełmie (od II połowy XV wieku z siedzibą w Krasnymstawie) stanowiło najczęściej tylko szczebel pośredni w drodze do najważniejszych i najlepiej uposażonych biskupstw (Kraków, Poznań, Gniezno). Dla wszystkich biskupów chełmskich w okresie nowożytnym było to pierwsze lub drugie biskupstwo w karierze. W ustaloną przez W. Müllera precedencję biskupstw wpisał się składający relację w 1594 r. Gomoliński, który został przeniesiony z diecezji kamienickiej, zaś po ukończeniu posługi w diecezji chełmskiej objął bardziej prestiżowe i lepiej uposażone biskupstwo w Łucku (Müller, „Diecezje w okresie potrydenckim"139, 244).

Wiarygodność relacji o stanie diecezji chełmskiej z 1594 r. może być dokonana tylko poprzez skonfrontowanie zawartych w niej informacji z innymi typami źródeł oraz stanem wiedzy. W dziejach diecezji chełmskiej jest to okres dość trudny i na te szczególne uwarunkowania zwraca uwagę autor relacji z 1594 r. Na plan pierwszy wysuwa się, powtarzany zresztą wielokrotnie, fakt przewagi ludności prawosławnej oraz funkcjonowania na jej terenie zbudowanych wcześniej struktur prawosławnych. Jak wskazują badania A. Janeczka (dla województwa bełskiego) (35-62), Bieńkowskiego i Gila (struktura parafii prawosławnych) (Bieńkowski, „Organizacja Kościoła wschodniego w Polsce” 930; Gil 187-191) oraz W. Czarneckiego i B. Szadego (struktura parafii łacińskich) (Szady 54-56; Czarnecki 47-48), na jedną parafię łacińską przypadało w tym okresie ok. pięć cerkwi prawosławnych. Terytoria diecezji prawosławnej i łacińskiej były do siebie bardzo zbliżone, przy czym liczba parafii prawosławnych pod koniec XVI wieku wahała się w granicach 350, zaś parafii łacińskich - ok. 70. Znaczna część z parafii łacińskich dodatkowo była w tym czasie objęta ruchem reformacyjnym. Relacja o stanie diecezji chełmskiej podaje tutaj dość wiarygodny szacunek - z 70 istniejących parafii aż 24 miało pozostawać w rękach protestanckich (Janeczek 51; Szady 56). Statystyka ta ilustruje sytuację w diecezji już po okresie największego nasilenia reformacji protestanckiej. Z powodu niedostatków źródłowych brakuje - jak dotąd - dokładnej analizy przebiegu reformacji na terenie tej diecezji. Niewątpliwie jednak skala zjawiska 
była znaczna, a wpływ na organizacyjne funkcjonowanie diecezji zgodny z opinią wyrażoną w relacji z 1594 r. Na skutek zajęcia przez protestantów przestały czasowo funkcjonować takie parafie, jak Bończa, Dub, Dzierążnia, Gorzków, Kryłów, Lipie, Łabunie, Przewały, Siennica, Sitaniec, Świerże, Uhrusk, Żerniki, Żółkiew. A. Wadowski podawał, że w sumie aż połowa świątyń w diecezji chełmskiej ucierpiała na skutek reformacji - 36 kościołów parafialnych zajętych przez protestantów oraz 11 opuszczonych (w tym jeden klasztorny): „Jakaż to straszna ruina Kościoła, gdy z 73 świątyń parafialnych, zostało zaledwie 26” (k. 18v-20).

Sieć kościołów parafialnych w diecezji chełmskiej, dodatkowo nadszarpnięta przez reformację, nie tworzyła regularnej i zwartej terytorialnie struktury. Parafie były dość rozległe, zaś odległości między kościołami znaczne - relacja z 1594 r. podaje, że niekiedy dystans ten wynosił ok. 15-20 mil włoskich, czyli ok. 22,5-30 km. Średnia odległość między dwoma najbliższymi parafiami, obliczona na podstawie mapy kościołów diecezji chełmskiej funkcjonujących ok. 1600 r. (62 parafie) (Szady 66-67), wynosiła $10400 \mathrm{~m}$. Kościołów parafialnych oddalonych od sąsiadujących świątyń tak bardzo, jak wskazuje relacja (powyżej $20 \mathrm{~km}$ ) było w diecezji zaledwie kilka: Ratno, Luboml, Orchów, Narol, Łopacin. Parafie położone w części zabużańskiej podnosiły średnią powierzchni przypadającą na jeden kościół parafialny w całej diecezji. Południowo-zachodnia część diecezji miała lepiej rozbudowaną sieć świątyń oraz okręgi parafialne o mniejszej powierzchni w porównaniu z częścią północno-wschodnią (Szady 56). Bardziej rozbudowana sieć parafialna w bełskiej części diecezji chełmskiej była związana z lepiej rozwiniętą siecią osadniczą oraz z rozwojem kolonizacji rycerskiej i nadaniami ziemskimi dla szlachty mazowieckiej w okresie panowania Piastów płockich na tym terenie (Janeczek 41; Czarnecki 49). Składający relację chciał wyraźnie podkreślić małą liczbę świątyń oraz znaczące odległości między nimi, co w sposób oczywisty utrudniało praktyki religijne i sprawowanie duszpasterstwa. Prawo patronatu nad beneficjami parafialnymi leżało w większości w rękach królewskich i szlacheckich. Większa przewaga patronatu szlacheckiego i mniejszy odsetek kościołów pod opieką króla i duchowieństwa to cecha wszystkich diecezji metropolii lwowskiej (Litak 98-99). Czynnik ten został wskazany w relacji jako jedna z przyczyn słabości organizacyjnej oraz materialnej beneficjów w diecezji chełmskiej. Lepsza kondycja parafii w dobrach królewskich i biskupich wynikała $\mathrm{z}$ trwałych podstaw materialnych, które dodatkowo rzadko były naruszane przez reformację. Ruch reformacyjny powiązany z przejęciem uposażenia beneficjów parafialnych objął przede wszystkim dobra szlacheckie. Relacja podaje, że w diecezji chełmskiej znajdowały się tylko cztery parafie ,ad collationem reverendissimi domini episcopi”. W rękopisie relacji słowo „tres” zostało przekreślone i pojawiła się interpolacja: „quatuor”. Bez wątpienia chodzi o cztery parafie funkcjonujące w dobrach biskupów chełmskich: Kumów, Sawin, Skierbieszów, 
Pawłów. Została natomiast pominięta parafia w Orchowie, co może wskazywać, że prawo patronatu nad tym beneficjum trafiło w ręce biskupów chełmskich w latach 1594-16027.

Przewaga ludności i struktur prawosławnych oraz apogeum rozwoju reformacji w diecezji to czynniki, które determinowały funkcjonowanie Kościoła łacińskiego na tym terenie na wielu płaszczyznach. Relacja odnosi się w większym stopniu do konsekwencji na polu tzw. „status materialis” niż „status formalis”. Pod pojęciem „status materialis” należy rozumieć organizację diecezji („loca urbana, suburbana, ruralia, silvestria, cathedralis, collegiatae, parochiales et aliae ecclesiae et oratoria, monasteria tam virorum quam mulierum, hospitalia, Montes Pietatis, collegia, confraternitates et alia pia loca tam civitatis quam dioecesis, earundem ecclesiarum et locorum situs, fabrica, ornatus, bona, redditus, sacra suppellex, personarum ac ministrorum numerus et ordo et alias his similia”). Określenie „status formalis” odnosiło się do dyscypliny kościelnej, realizacji obowiązków duszpasterskich i organizacyjnych, wdrażania uchwał soboru trydenckiego itp. Analiza relacji z 1594 r. wskazuje, że „status formalis” w diecezji chełmskiej był uwarunkowany przez jej „status materialis” (Długosz, „Biskupia «visitatio liminum»” 243-244).

Autor relacji poświęcił wiele uwagi kwestii uposażenia beneficjów w diecezji. Nie podał wprost wysokości dochodów biskupstwa, ale skupił się raczej na niedogodnościach związanych z rozproszeniem dóbr stołowych, ich złym stanem z powodu zniszczeń wojennych oraz trudnościami w egzekwowaniu świadczeń (procesy sądowe). Biskupstwo chełmskie rzeczywiście należało do słabiej uposażonych w Rzeczypospolitej. Nie chodzi tylko o porównanie z diecezjami metropolii gnieźnieńskiej, ale także z biskupstwami we Lwowie, Przemyślu i Łucku. Dochód biskupstwa miał się kształtować między 3 a 6 tys. florenów rocznie w zależności od poziomu realizacji świadczeń na rzecz biskupa (Długosz, „Biskupi polscy XVII i XVIII w. 95; Dybkowska 121; Szady 46). Być może dlatego biskup Gomoliński objął w komendę w 1598 r. dochodowe opactwo benedyktyńskie w Sieciechowie (Chłapowski 166, 179). Zaniżony wydaje się natomiast podany w relacji dochód członków kanoników - mieli oni otrzymywać rocznie 8 dukatów uposażenia oraz dodatkowo 10 dukatów z tytułu tzw. dystrybucji codziennych, które przynależały prałatom i kanonikom dopełniającym obowiązku rezydencji. Te skromne kwoty

\footnotetext{
${ }^{7}$ Feliks Skroberski objął parafię w Orchowie w 1602 r. na podstawie patronatu biskupiego: ,vigore iurispatronatus a generoso domino Nicolao Iwicky in Orchow haerede, praedecessoribus et successoribus episcopis Chelmensibus perpetuo dati”, AAL. Rep60 A106, k. 46v-47. Patronat biskupów chełmskich nad tą parafią potwierdza pierwsza zachowana wizytacja diecezji z 1604 r. „Ecclesia nondum est consecrata, cuius iuspatronatus est dominorum episcoporum Chełmensium a collatoribus et patronis donatum", AAL. Rep60 A149, k. 117.
} 
odpowiadają raczej sumom pobieranym na podstawie pierwotnego uposażenia kapituły. Dochody kanonickie były bardziej zróżnicowane i obejmowały w II połowie XVI wieku kilka kategorii: refekcje, prezencje, środki prebendalne (fundi), tzw. równe podziały. Należy też pamiętać o kilku parafiach, których uposażenie zostało inkorporowane do kapituły (Chełm, Biała, Drohobycz). Parafie Biała (Rawska) i Drohobycz leżały na terenie innych diecezji - odpowiednio: poznańskiej i przemyskiej. Dokładny szacunek uposażenia przypadającego na jednego kanonika jest o tyle skomplikowany, że do II połowy XVI wieku nie ukształtował się w kapitule chełmskiej system prebendalny (Pałka, „Źródła uposażenia kapituły chełmskiej obrządku łacińskiego" 29-47; Marczewski 408-16).

Uposażenie i kondycja materialna beneficjów szły w parze ze stanem budynków kościelnych - zarówno samych kościołów, jak i innych zabudowań diecezjalnych (domy dla duchowieństwa, zabudowania gospodarcze). O samym kościele katedralnym relacja nie mówi wiele. Podobnie jak miasto Krasnystaw i inne zabudowania kościelne ulegał w II połowie kilkakrotnym pożarom i zniszczeniom. Zwraca jednak uwagę fragment poświęcony częstym translacjom kościoła katedralnego. W bezpośrednim następstwie pożaru Chełma w 1473 r. Paweł z Grabowej, biskup chełmski, wystarał się u króla Kazimierza Jagiellończyka o zgodę na przeniesienie stolicy diecezji z Chełma do bardziej ludnego i lepiej rozwiniętego gospodarczo w tym czasie Hrubieszowa. W literaturze przedmiotu toczyła się polemika na temat realizacji tego postanowienia - ostatecznie B. Kumor, a za nim J. Marczewski podważyli realizację postanowień dokumentu translacyjnego z 1473 r. Dziwić może zatem stwierdzenie odnoszące się do kościoła parafialnego, zawarte w relacji z 1594 r.: „Quod iam in tertium locum translata sit”. Jeżeli autor relacji odnosił się do stanu faktycznego, a nie formalnego, poświadczonego jedynie w dokumentach, to wzmianka ta może pośrednio wskazywać na czasowe przeniesienie stolicy diecezji z Chełma do Hrubieszowa (1473), przed jej trwałą translokacją do Krasnegostawu (1490) (Pałka, „Powstanie katedralnej kapituły 20-26; Kumor 369-380; Marczewski 59-69).

Słabe uposażenie zarówno biskupstwa, prebend w kapitule katedralnej, parafii oraz niższych beneficjów wpływało na liczbę duchowieństwa w diecezji oraz trudności w zapewnieniu obsługi duszpasterskiej przez dobrze przygotowanych do posługi księży. Problem ten oraz metody jego rozwiązania zajmuje najwięcej miejsca w relacji z 1594 r. Szereg propozycji i próśb skierowanych do Stolicy Apostolskiej układa się w dobrze przemyślany, prowadzony na wielu polach, program poprawy sytuacji w diecezji. Powiększenie uposażenia beneficjów oraz ich dochodów było trudne na obszarze, gdzie silną organizację miał Kościół prawosławny i toczyła się walka o przywrócenie majątku utraconego w okresie reformacji. Proponowane w relacji rozwiązania zmierzają dość wyraźnie w kierunku konsolidacji majątku beneficjalnego. Miały temu służyć uproszczenia proceduralne w obrocie majątkiem 
kościelnym (zamiana, sprzedaż, kupno). Drugim z proponowanych rozwiązań było uproszczenie procesu łączenia beneficjów (unio beneficiorum), które należy odróżnić od ich kumulacji przez duchowieństwo. Dotyczyło to zarówno możliwości łączenia beneficjów katedralnych z parafialnymi, jak i dwóch słabo uposażonych parafii. Uproszczenia proceduralne miały polegać głównie na przekazaniu decyzji w wymienionych wyżej sprawach w ręce nuncjusza apostolskiego w Rzeczypospolitej i biskupa miejsca. Pojawiła się nawet konkretna propozycja przeniesienia jednego z dobrze uposażonych, a słabo obsadzonych klasztorów dominikanów (Hrubieszów, Bełz, Horodło) do Krasnegostawu dla poprawy sytuacji materialnej biskupstwa oraz duchowieństwa katedralnego. Sprawa nie znalazła dalszego ciągu w kontekście sporów przy kształtowaniu prowincji ruskiej dominikanów. W 1598 r. biskup Gomoliński potwierdził przynależność trzech wymienionych klasztorów do prowincji polskiej (Świętochowski 67).

Z kwestią niedoborów duchowieństwa wiąże się zagadnienie niedopełniania obowiązku rezydencji oraz kumulacja beneficjów kościelnych. W diecezji chełmskiej te powszechne w Kościele potrydenckim mankamenty nie wynikały z zachłanności czy też chęci wzbogacenia się duchowieństwa, ale z konieczności zapewnienia minimalnej choćby obsady parafii. Stan organizacyjny oraz materialny beneficjów nie umożliwiał walki z kumulacją beneficjów. Głównym problemem było to, że duchowni posiadający ubogie beneficja w diecezji chełmskiej przebywali przy swoich głównych prebendach zlokalizowanych w innych diecezjach. Proponowane w relacji rozwiązania prawne nie idą więc w kierunku likwidacji kumulacji beneficjów, ale zmierzają do poprawy w zakresie realizacji obowiązku rezydencji (Pałka, „Obowiązek rezydencji prałatów” 226). Kumulacja beneficjów duszpasterskich, która z mocy prawa było zabroniona (incompatibilia), opierała się na dyspensach udzielanych przez Stolicę Apostolską. Jeżeli duchowny posiadał taką dyspensę, to biskup diecezjalny miał ograniczone możliwości przymuszenia duchownego do rezydowania przy określonym beneficjum. Stąd prośba o udzielanie dyspens uwarunkowanych obowiązkiem rezydowania przy beneficjum w diecezji chełmskiej. Istotną rolę przy organizacji duszpasterstwa opartego na łączeniu i kumulacji beneficjów odgrywało duchowieństwo pomocnicze, np. wikariusze wieczyści przy inkorporowanych kościołach parafialnych. Oprócz poprawy uposażenia oraz ułatwień dotyczących łączenia i kumulacji (przy zachowaniu obowiązku rezydencji) sytuację kadrową w diecezji miała poprawić możliwość udzielania święceń bez pozwolenia biskupa diecezji, z której pochodził duchowny (litterae dimissoriales), zapowiedź utworzenia seminarium duchownego (powstało dopiero w 1642 r.) oraz współpraca $\mathrm{z}$ akademią i kolegiatą w Zamościu.

Relacja o stanie diecezji chełmskiej z 1594 r., w porównaniu z innymi relacjami przesłanymi w następnych stuleciach z polskich diecezji, jest krótka i ma dość 
ogólny charakter. Nie informuje w sposób systematyczny i regularny o wszystkich aspektach organizacyjnych i duszpasterskich życia w diecezji. Jej wartość informacyjna, zwłaszcza przy analizie poszczególnych problemów czy konkretnych zagadnień, ma charakter jedynie uzupełniający. Większą wartość relacje o stanie diecezji do Stolicy Apostolskiej mogą przedstawiać przy badaniu stosunku biskupa do swojej diecezji oraz sposobu zarządzania. Dlatego warto na to źródło patrzeć w kontekście porównawczym - zwłaszcza przez pryzmat relacji składanych przez tego samego biskupa z różnych diecezji, które pozostawały w jego zarządzie w ciągu kariery duchownej. Umożliwi to pełniejszą analizę tego źródła oraz odpowiedź na pytanie, w jakim stopniu relacje były osobistym dziełem danego biskupa, a w jakim środowiska kurii biskupiej i w jakimś zakresie tradycji biskupstwa (Kłoczowski 260).

\section{BIBLIOGRAFIA}

BieŃKowski, Ludomir. „Działalność organizacyjna biskupa Jana Biskupca w diecezji chełmskiej (1417-1452)”. Roczniki Humanistyczne, t. 7, nr 2, 1958, ss. 187-256.

BiEŃKOwski, Ludomir. „Nieznany synod diecezji chełmskiej obrządku łacińskiego w 1593 r.” Sprawozdania z Czynności, Wydawnictw i Posiedzeń Naukowych oraz Kronika Towarzystwa Naukowego KUL, r. 11, 1960, ss. 97-98.

BieŃKOwski, Ludomir. „Organizacja Kościoła wschodniego w Polsce”. Kościół w Polsce, red. Jerzy Kłoczowski, t. 2, Znak, 1969-1970, ss. 779-1049.

BORATYŃSKI, Ludwik. „Najdawniejsze relacye biskupów polskich o stanie dyecezyi (relationes status ecclesiarum) z archiwum Kongregacyi del Concilio w Rzymie”. Sprawozdania z Czynności i Posiedzeń Akademii Umiejętności w Krakowie, t. 21, nr 5, 1916, ss. 27-45.

CHŁAPOWSKI, Krzysztof. Elita senatorsko-dygnitarska Korony za czasów Zygmunta III $i$ Władystawa IV. Wydawnictwo Sejmowe, 1996.

CZARneCKI, Włodzimierz. „Rozwój sieci parafialnej Kościoła łacińskiego w ziemi chełmskiej do początku XVII w." Roczniki Humanistyczne, t. 48, nr 2, 2000, ss. 29-89.

DŁugosz, Teofil. „Biskupia «visitatio liminum»: instrukcje kongregacji odnośnie do relacyj biskupich: (dokończenie)". Collectanea Theologica, t. 14, nr 3-4, 1933, ss. 273-388.

DŁugosz, Teofil. „Biskupia «visitatio liminum»”. Collectanea Theologica, t. 14, nr 1-2, 1933, ss. $173-$ 249.

DŁugosz, Teofil. „Biskupi polscy XVII i XVIII w. Obsada, dyspensy, taksy”. Roczniki Teologiczno-Kanoniczne, t. 5, nr 2, 1958, ss. 73-98.

DŁugosz, Teofil. „Wartość relacji rzymskich biskupów polskich jako źródła historycznego”. Sprawozdania z Czynności Wydawniczej i Posiedzeń Naukowych oraz Kronika Towarzystwa Naukowego KUL, r. 12, 1961, ss. 89-92.

DyвкоwSKA, Alicja. „O powoływaniu biskupów za ponowania Zygmunta Augusta”. Między monarcha a demokracja. Studia z dziejów Polski XV-XVIII wieku, red. Anna Sucheni-Grabowska, Małgorzata Żaryn, Wydawnictwo Sejmowe, 1994, ss. 116-142.

GiL, Andrzej. Prawosławna eparchia chetmska do 1596 roku. Prawosławna Diecezja LubelskoChełmska, 1999. 
Instrukcja wydawnicza dla średniowiecznych źródeł historycznych. Drukarnia Uniwersytetu Jagiellońskiego; nakł. Polskiej Akademii Umiejętności, 1925.

JANECZEK, Andrzej. Osadnictwo pogranicza polsko-ruskiego. Województwo betskie od schytku XIV do poczatku XVII w. Instytut Archeologii i Etnologii PAN, dawniej Instytut Historii Kultury Materialnej PAN, 1993.

KŁoczowski, Jerzy. „Kwerenda polska w archiwach watykańskich w 1962 roku”. Przeglad Historyczny, t. 55, nr 2, 1964, ss. 257-266.

KopIEC, Jan. Relacje ,, ad limina apostolorum” z diecezji wrocławskiej z lat 1589-1943. Edycja tekstów źródtowych. Wydział Teologiczny UO, 2014.

Kościół w Polsce, red. Jerzy Kłoczowski, Znak, 1969-1970.

Kumor, Bolesław. „Przeniesienie stolicy biskupiej z Chełma do Krasnegostawu (1490)”. Archiwa, Biblioteki i Muzea Kościelne, t. 49, 1984, ss. 369-380. doi:10.31743/abmk.7695.

LEPSZY, Kazimierz. Instrukcja wydawnicza dla źródet historycznych od XVI w. do poł. XIX w. Zakład im. Ossolińskich, 1953.

LePszy, Kazimierz. „Gomoliński Stanisław h. Jelita (zm. 1604)”. Polski słownik biograficzny, t. 8, red. Kazimierz Lepszy, Zakład im. Ossolińskich, 1959-1960, ss. 272-273.

LitaK, Stanisław. Parafie w Rzeczypospolitej w XVI-XVIII wieku. Struktura, funkcje spoteczno-religijne i edukacyjne. Wydawnictwo KUL, 2004.

MarCZewski, Jarosław Roman. Dzieje chetmskiej kapituły katedralnej obrządku łacińskiego. Wydawnictwo KUL, 2013.

MüLLER, Wiesław. „Diecezja krakowska w relacjach biskupów z XVII i XVIII w.” Roczniki Humanistyczne, t. 13, nr 2, 1965, ss. 5-149.

MüLLER, Wiesław. „Diecezje w okresie potrydenckim”. Kościót w Polsce, red. Jerzy Kłoczowski, t. 2, Znak, 1969-1970, ss. 55-258.

PAŁKa, Paweł. „Powstanie katedralnej kapituły obrządku łacińskiego w Chełmie i przeniesienie jej do Krasnegostawu”. Roczniki Teologiczno-Kanoniczne, t. 17, nr 5, 1970, ss. 15-26.

PAŁKA, Paweł. „Źródła uposażenia kapituły chełmskiej obrządku łacińskiego”. Roczniki TeologicznoKanoniczne, t. 20, nr 5, 1973, ss. 29-47.

Palka, Paweł. „Obowiązek rezydencji prałatów i kanoników katedralnej kapituły chełmskiej w Krasnymstawie". Prawo Kanoniczne, t. 28, nr 3-4, 1985, ss. 223-236.

PrZYGodzKi, Stanisław. „Bulla papieża Sykstusa V «de visitandis liminibus Apostolorum» i stanowisko wobec niej biskupów polskich". Collectanea Theologica, t. 13, nr 4, 1932, ss. 298-323.

Relacje arcybiskupów lwowskich 1595-1794. Wyd. Teofil Długosz, 1937.

Relacje o stanie diecezji krakowskiej: 1615-1765. Wyd. Wiesław Müller, 1978.

Relationes status dioecesium in Magno Ducatu Lituaniae. Wyd. Paulus Rabikauskas, 1971-1978.

SchmiduIn, Josef. Die kirchlichen Zustände in Deutschland vor dem Dreißigjärigen Kriege nach den bischöflichen Diözesanberichten an den Heiligen Stuhl. Herder 1908-1910.

SzADY, Bogumił. „System beneficjalny diecezji chełmskiej w latach 1600-1621”. Roczniki Humanistyczne, t. 45, nr 2, 1997, ss. 39-68. doi:10.5281/zenodo.3690153.

Szorc, Alojzy. „Relacje biskupów warmińskich XVII i XVIII wieku do Rzymu o stanie diecezji”. Studia Warmińskie, 1968, ss. 201-239.

Świętochowski, Robert. „Początki dominikańskiej prowincji ruskiej (1596-1602)”. Prawo Kanoniczne, t. 23, nr 1-2, 1980, ss. 51-86.

WADowski, Jan Ambroży. Materiały do dziejów diecezji chetmskiej. Biblioteka PAN w Krakowie, rkps. 2372/I.

Wóscıк, Walenty. „Wizytacje biskupów polskich «ad limina» do roku 1911”. Prawo Kanoniczne, t. 18 , nr 3-4, 1975, ss. 131-179.

Wyczawski, Hieronim Eugeniusz. Przygotowanie do studiów w archiwach kościelnych. Calvarianum, 1989. 


\section{ORGANIZACJA I FUNKCJONOWANIE DIECEZJI CHEŁMSKIEJ W ŚWIETLE RELACJI „AD LIMINA”Z 1594 R.}

Streszczenie

Głównym celem artykułu jest ocena wiarygodności oraz krytyka wartości źródłowej pierwszej relacji o stanie diecezji chełmskiej z 1594 r. w odniesieniu do stanu organizacyjnego diecezji w końcu XVI wieku, czyli przed pożarem archiwum kurii biskupiej w Krasnymstawie (7 kwietnia 1597), w którym spłonęła większość dokumentów i ksiąg. Analizowany w tekście raport jest jedną z dwóch najstarszych zachowanych relacji przesłanych przez polskich biskupów do Stolicy Apostolskiej po soborze trydenckim.

Krytyka relacji chełmskiej z 1594 r. poprzedzona została wstępem odnoszącym się do tradycji badawczej oraz edytorskiej związanej z tą kategorią źródeł. Przedstawione zostały okoliczności i kontekst historyczny powstania relacji. Ocena wiarygodności informacji przekazanych do Stolicy Apostolskiej przez pełnomocnika biskupa Stanisława Gomolińskiego została dokonana poprzez analizę porównawczą treści relacji z informacjami na temat stanu i organizacji diecezji chełmskiej pochodzącymi z innych źródeł oraz opracowań naukowych. Autor relacji wskazał szereg trudności w funkcjonowaniu swojej diecezji na obszarze, gdzie przeważała Cerkiew prawosławna, a sieć kościołów łacińskich, dodatkowo nadszarpnięta przez reformację, nie tworzyła regularnej i zwartej terytorialnie struktury. Powodowało to trudności w materialnym zabezpieczeniu beneficjów oraz zapewnieniu obsługi duszpasterskiej (brak duchowieństwa, kumulacja beneficjów, niedotrzymywanie obowiązku rezydencji).

Relacja z 1594 r., w porównaniu z późniejszymi relacjiami, ma charakter listu (stylus epistolaris), a nie formularza, jest krótka i dość ogólna. Jej wartość informacyjna, zwłaszcza przy analizie poszczególnych problemów czy konkretnych zagadnień, ma charakter jedynie uzupełniający. Większą wartość może przedstawiać przy badaniu stosunku biskupa do swojej diecezji oraz sposobu zarządzania. Warto patrzeć na to źródło w kontekście porównawczym - szczególnie przez pryzmat relacji składanych przez tego samego biskupa $\mathrm{z}$ różnych diecezji, które pozostawały w jego zarządzie w ciągu kariery duchownej. Umożliwi to pełniejszą krytykę tego źródła oraz odpowiedź na pytanie na ile relacje były osobistym dziełem danego biskupa a na ile środowiska kurii biskupiej, i w jakimś zakresie tradycji biskupstwa.

Słowa kluczowe: Reforma trydencka; relacje „ad limina”; diecezja chełmska; Stanisław Gomoliński; źródła kościelne.

\section{THE ORGANIZATION AND FUNCTIONING OF THE CHEŁM DIOCESE IN THE LIGHT OF THE “AD LIMINA” ACCOUNT FROM 1594}

\section{Sum mary}

The major aim of the present article is to assess the credibility and provide criticism of the source value of the first account on the state of the Chelm diocese from 1594 in reference to the organizational state of the diocese at the end of the 16th century, which was before the fire of the archives of the Episcopal curia in Krasnystaw (7 April, 1597), when most of the documents and books burnt down. The account analyzed in the present text is one of the oldest preserved reports sent by the Polish bishops to the Apostolic See after the Council of Trent. The criticism of the Chelm account from 1594 is preceded by an introduction referring to the research tradition and the editorial tradition related to this category of sources. The circumstances and the historical context concerning the account are presented. The evaluation of the reliability of the information passed to the Apostolic See by the representative of bishop Stanisław Gomoliński was conducted by means of the comparative analysis referring to the content of the account together with the information on the state and organization of 
the Chełm diocese which comes from other sources and scientific studies. The author of the account pointed to a number of difficulties in the functioning of his diocese in the area where the Orthodox Church prevailed and the network of Latin churches, additionally weakened by the Reformation, did not make up a regular and compact territorial structure. This caused a lot of problems in the material protection of the benefices and in pastoral services (a lack of clergymen, accumulation of benefices, disregarding the duty of residence).

The account from 1594, as compared to later reports, has the character of a letter ("stylus epistolaris"), and not a form. It is short and fairly general. Its informative value, especially when we analyze particular problems or particular issues, is only supplementary. It can present greater value while studying the bishop's relation to his diocese and the way of managing it. It is worth looking at this source in the comparative context - especially through the prism of the accounts presented by the same bishop from various dioceses which were under his management during his pastoral career. This will enable criticism of this source and the answer to the question about the extent to which the accounts were the personal work of a given bishop or the work of the Episcopal curia circles and to what extent the traditions of the bishopric.

Keywords: Trent reform; "ad limina” accounts; Chełm diocese; Stanisław Gomoliński; church sources. 


\section{ANEKS $^{8}$}

[Relacja o stanie diecezji chetmskiej, 1594], Archivio Apostolico Vaticano, Congr. Concilio, Relat. Dioec. 217, k. 9-12 (oryginalna foliacja: $k .472-475$ ).

[k. 9] Reverendissimus dominus Stanislaus Gomolinsky episcopus Chelmensis ex Camenecensi episcopatu ad Chelmensem a faelicis recordationis Gregorio Papa XIIII translatus, multos in eo deffectus et incommoda invenit. Dioecesim satis vastam et amplam. Catholicos in ea paucos, cum tota plebs schismatica sit, nam ante septingentos et amplius annos, fidem Christianam a Graecis in hac parte acceperunt, in qua tota plebs adhuc permanet non solum in civitatibus et villis regiis et nobilium, verum etiam in episcopalibus (ut in hac metropoli Leopoliensi). Nobiles vero plerique haeretici, cumque episcopatus non valde antiquus, a ducentis annis vel circa erectus sit, et schismatici cleri et ecclesiarum earundem proventus legibus firmati existant, decimae tantum ex praediis regiis assignatae sunt et maior pars bonorum regiorum in haereditatem nobilibus data est, qui per totum regnum fere nullas decimas persolvunt, necessario subsequuta est penuria cleri, cum in hac dioecesi valde pauci inveniantur, qui ordines sacros suscipere velint vel possint, stantibus schismate et haeresi suprascriptis ac defectu proventuum ob non solutionem decimarum. Ex aliis etiam dioecesibus difficillime huc adducuntur, cum ubique commodius quam hic manere possint, ubi (ut supra dictum est) sufficientem victum non habent, ita ut multae ecclesiae et parochiales sacerdote et rectore careant, cum multae ex eis non modo uno sacerdote, sed etiam pluribus indigerent, nam una ab altera distat quandoque quindecim aut viginti milliaribus Italicis et sub una parochia sunt quindecim aut viginti villae, plus vel minus, et villae istae non sunt parvae, nam in aliquibus ducentae domus et ultra reperiuntur, in quibus licet (ut supradictum est) sint schismatici, inveniuntur etiam ex Polonia advenae catholici et licet una aut duae tamen familiae catholicorum in qualibet villa sint, nihilominus etiam pro uno cogitur sacerdos (quando infirmatur) proficisci ad administrandum illi sacramentum Sanctissimae Eucharistiae et Extremae Unctionis et multoties accidit, ut in duabus villis inter se distantibus, aut etiam in pluribus, uno et eodem tempore infirmi sint, qui eisdem sacramentis indigent et licet ad unam tantum; aliquando propter malum iter et pluvias et alia incommoda vix potest sacerdos vocatus accedere, cum (ut supra dictum est) unus tantum in una ecclesia sit, cui deffectui non potest provideri, cum (ut praefertur) decimae, quae in Polonia multis in locis non solvuntur, hic nunquam solvi consueverunt, nam ipsi Rutheni in qualibet villa habent suam ecclesiam. Cum vero tam parvus numerus [k. $9 v]$ sacerdotum in dioecesi sit et maior esse non possit, et parochiae in dioecesi sint septuaginta et ultra (ex quibus viginti quatuor ab haereticis reverendissimus devastatas reperiit, licet iam tres aut quatuor ab ipso reconciliatae sint), non modo id fieri non potest, ut plures sacerdotes in una ecclesia sint, sed multoties quaerendus esset unus idoneus, qui duas parochiales regere vellet. Hinc etiam

\footnotetext{
${ }^{8}$ Zob. przyp. 1.
} 
fit, ut in sacrorum ordinum collatione, in ecclesiarum consecratione et visitationibus et in aliis pontificalibus actibus et exercitiis reverendissimus convenientem assistentiam cleri non habeat, licet saepius ecclesias consecrare cogatur, cum admodum paucas in hac dioecesi, imo vero neque ipsam cathedralem nec Chelmensem, nec alias in bonis episcopalibus consecratas repererit (cum praedecessores illius parum aut nihil in dioecesi residerint), quas reverendissimus consecravit maximo ipsius incommodo et sumptibus, cum cogatur pro dignitate episcopali et senatoria tuenda et etiam ad obviandum scandalis, quae ex licentia nobilium et praesertim haereticorum hic oriri possent, multis comitantibus incedere et suo sumptu, cum hic non sit moris (quemadmodum fit alibi), ut episcopo aliquid contribuant neque populus (quorum minor pars est catholica), neque plebani, cum pauperes sint; et in dioecesi tam vasta aliquando centum milliaria Italica et aliquando plus ad consecrationem unius ecclesiae proficisci contingat neque episcopus Chelmensis suffraganeum habeat (sicut alii multi huius regni episcopi habent), qui in supportandis oneribus huiusmodi illum adiuvet. In hac etiam dioecesi beneficia sunt modicorum reddituum et pauca et sunt aut iuris patronatus regii, aut nobilium. In tota autem dioecesi -tres- $<$ quatuor $>^{9}$ tantum parochiales sunt ad collationem reverendissimi domini episcopi. Ordinati vero ad sacros ${ }^{10}$ ordines ex alienis dioecesibus venire hic non possunt, cum a propriis episcopis cogantur obligationem facere de non discedendo a dioecesi. Seminarium autem propter cleri inopiam et exiguos redditus reverendissimi domini episcopi in hac dioecesi hactenus erigi non potuit neque ad praesens potest, licet de eo erigendo in synodo, quam anno praeterito cellebravit satis superque actum sit. Paucissimi etiam sunt inventi confirmati, ita ut cum reverendissimus dioecesim visitan [do?] obiret nullos fere confirmatos invenit praeter eos, qui advenae ex aliis dioecesibus fuerunt, ita ut multi nonagenarii et ultra sacramentum confirmationis acceperint.

Ecclesiae vero cathedralis status huiusmodi est. Quod iam in tertium locum translata sit idque propter maiorem copiam Ruthenorum, schismaticorum, Iudaeorum, haereticorum in his [k. 10] civitatibus degentium, ex quibus est translata, ubi nullum decorem et honestatem decentem habere potuit. In hac tandem civitate Crasnostaviensi, ubi nunc constituta est, iam ter per triginta plus vel minus annos igne conflagrata est, ex quo magnum dispendium in calicibus, vasis, ornamentis aliisque supellectilibus ecclesiae, usibus deputatis ita passa est, quod nec nunc quidem suos deffectus resarcire potest, quandoquidem non habeat suam provisionem tantam, quae huiusmodi necessitatibus illius sufficere possit et nisi eleemosinis catholicorum paucorum adiuvaretur, actum esset, quod nec divina officia sacrosanctaeque missae sacrificium suam necessitatem ad illa pertinentem vix habere possint.

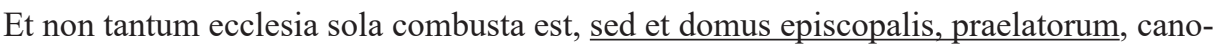
nicorum, vicariorum et aliorum sacerdotum solo aequatae sunt, quarum hucusque vix quinta pars propter deffectum constructa est, hinc est, ut in ea pauci praelati et sacerdotes resideant, qui propter extremam inopiam quodammodo excusandi videntur, octo tantum ducatorum

${ }^{9}$ Stowo: tres jest przekreślone, quatuor zapisane jako interpolacja wstawiona nad wierszem.

${ }^{10}$ Przekreślony dopisek na marginesie: petendum est istud indultum a Summo Pontifice, qui attentis narratis facile concedet illud. 
proventus annui eorum cuilibet assignati sunt, et residentibus pro quotidianis distributionibus alii decem, ex quibus se nullo modo sustentare possunt. Aliqui vero ex eis sufficientes redditus ad sui sustentationem habent ex beneficiis, quae in aliis dioecesibus habent, sed cum hi dispensationem a Sede Apostolica ad pluralitatem beneficiorum obtinuerint, malunt Cracoviae aut Leopoli, aut alibi residere, licet a primaeva fundatione praelaturarum et canonicatuum ad residentiam $[s]$ sub paena privationis teneantur, neque a reverendissimo domino episcopo ad residendum cogi possunt, cum in praefatis dispensationibus locus ad residendum certus illis assignatus sit in aliis ecclesiis, quae clero abundant. Schola valde parva, magistri enim tenues proventus habent, nec qui theologicas lectiones iuxta sacri concilii Tridentini decreta perlegat inveniri possent ob inopiam vicariorum et aliorum sacerdotum, numerus ${ }^{11}$ iuxta fundationem in eadem ecclesia cathedrali desideratur, qui propter tenuitatem reddituum, restitui non possent $[s]$. Praelati etiam et canonici supradicti, qui (ut praefertur) licentiam de non residendo habent, suos vicarios in cathedrali ecclesia (ut tenentur) tenere negligunt, propter quem deffectum sacerdotum et assistentiam $[s]$ praelatorum, episcopus cogitur multoties abesse ab ecclesia cathedrali et in diebus festivitatum maiorum. Circa eam vero ipsam morari non modo difficile, verum etiam impossibile est. Cum in civitate, in qua est, habitationem non habeat ipsiusque egestas non permittat [k. $10 \mathrm{v}]$ eum ibi illam extruere. Et licet illam haberet, inquiete et non pro decore episcopatu[s] ibidem commoraretur, cum in civitate ipsa fere totus senatus seu consulatus illius schismatici sint ecclesiasque suas lapideas habeant nostris elegantiores et episcopo convenientem reverentiam non exhibeant habeantque ipsi suum multo ditiorem, cui obtemperant, nobilitas autem licenciose $[s]$ admodum se gerat in civitatibus regiis.

Bona vero mensae episcopalis (quorum proventus sunt adeo tenues, ut nullo modo ad gradum episcopalem, cui senatorius est adiunctus, honesti sustentandum sufficiunt) invenit reverendissimus episcopus militum licentia $[s]$ et multoties Tartarorum incursionibus exposita, bonum oeconomum desiderantia, cum (ut supra dictum est) praedecessores illius parum aut nihil resederint, et propterea fere ad nihilum redacta et dilaniata sint et res (in curia eorum depraecessorum $[s]$ ) adeo devenerat, ut vix non omnia bona episcopatus litigiose sunt amissa, sed diligentia reverendissimi pleraque et ea, quae sunt maioris momenti, composita sunt. Praedia et villae episcopales distant inter se viginti aut ad minus quindecim milliaribus Italicis. Multoties reverendissimus pro eorundem bonorum defensione et alienatorum ac usurpatorum recuperatione cogitur iure agere et cum in Polonia non sit moris (quemadmodum in Italia), ut episcopus ipse iudicet, cogitur in diversis tribunalibus, sub quorum iurisditione $[s]$ eadem bona, ut praefertur, disiuncta ${ }^{12}$ posita sunt, maximis sumptibus iudices saeculares adire pro defensione aut recuperatione eorundem bonorum, aut ad eos procuratores mittere, comitia et generalia regni magno sumptu et comitatu adire tenetur, quae quolibet biennio celebrantur et sepissime $[s]$ singulis annis ${ }^{13}$.

\footnotetext{
${ }^{11}$ Korektura spowodowana poprawkami w sktadni zdania.

${ }^{12}$ Korektura, przekreślone stowo, prawdopodobnie: disumpta.

${ }^{13}$ Fragment: et sepissime [s] singulis annis inna ręka, pismem pospiesznym i pochylonym.
} 
Locum in bonis mensae episcopalis ad habitandum nullum commodum habet, ita ut in dioecesi (ut semper hucusque fecit) residere volens, coatus fuerit intra limites illius bona aliqua nobilium conducere, in quibus ad praesens commoratur.

Quod si a Sanctissimo Domino Apostolico concederetur huius dioecesis clero et praelatis et canonicis ecclesiae cathedralis nunc et pro tempore existentibus ${ }^{14}$, ut $<$ plura $>^{15}$ beneficia ecclesiastica $<\mathrm{et}^{16}$ in aliis dioecesibus (quemadmodum a faelicis recordationis Sixto Papa V. clero Camenecensi reverendissimo illius episcopatum $[s]$ agente pontificis vita durante concessum est, praelatis quidem et canonicis usque ad summam et valorem annuatim ducentorum [k. 11] ducatorum auri de camera, secundum communem extimationem ${ }^{17}$ ) impetrare et retinere possent adiecta conditione, ut in hac dioecesi residerent et ita ut reverendissimus dominus nuntius apostolicus in hoc regno pro tempore commorans, cleri huius rationem habere teneretur circa collationem beneficiorum vacantium in mense Sanctitatis Suae, nec non si Sanctitas Sua indulgeret, ut beneficia aliqua ecclesiastica et curata aliarum dioecesum pro tempore vacantia aut aliqua abbatia mensae capitulari et vicariis ac clero eiusdem ecclesiae cathedralis ad effectum, ut commodam sustentationem haberent, uniri possent. Et si parochialibus ecclesiis, quae a praelatis et canonicis huius cathedralis in hac dioecesi obtinentur et in posterum obtinebuntur, ut per vicarios perpetuos (assignata illis competenti fructuum parte ad eorum sustentationem) disserviri $[s]$ possent ipsique praelati et canonici circa cathedralem ecclesiam et assistentiam episcopi morarentur et ab animarum cura (per praefatos vicarios exercenda) exempti essent, ex dispensatione apostolica elargiretur. Et si facultas daretur reverendissimo domino episcopo, ut ex alienis dioecesibus absque etiam dimissorialibus litteris idoneos et bene examinatos, qui in dioecesi ad brevius tempus, quam de iure praescriptum est, morarentur quique in hac dioecesi permanere velint ${ }^{18}$, ad ordines promovere posset, profecto deffectui supradicto paucitatis cleri huius dioecesis et cathedralis ecclesiae provideretur. Cui non parum adiumenti allaturam sperat reverendissimus universitatem, quam dominus regni cancellarius in civitate Samosciensi, huius dioecesis nuper erexit, ex qua (procul dubio) multi in probos viros evadent ${ }^{19}$. Et si ex ecclesia collegiata eiusdem civitatis Samosciensis decanus nunc et pro tempore existens a Sanctissimo Domino Nostro in suffraganeum episcopi Chelmensis ${ }^{20}$ et nunc et pro tempore existentis daretur, ut supportandis praedictis oneribus dioecesis huius reverendissimum dominum episcopum adiuvaret, adiuncto illi aliquo beneficio. Ipse quidem minori comitatu et sumptu villas distantes abire consecrare et alia episcopi officia obire facilius posset, praesertim cum

${ }^{14}$ Dopisek na marginesie: petendum a Summo Pontifice, qui causis praenarratis motus facile indulgetur.

${ }^{15}$ Stowo zapisane jako interpolacja wstawiona nad wierszem.

${ }^{16}$ Stowo zapisane jako interpolacja wstawiona nad wierszem.

${ }^{17}$ Fragment dopisany na marginesie: aliis vero, prout vicariis et parochis centum ducatorum similium.

${ }^{18}$ Fragment dopisany na marginesie: similiter petendum a Pontifice.

${ }^{19}$ Lekcja niepewna. Możliwa forma: evadant.

${ }^{20}$ Korektura: wytarcie i nadpisanie. 
alii episcopi hic residere non solent et difficillime possunt et comitiorum et aliorum negotiorum regni causa multoties abesse tenentur.

Et si reverendissimo domino episcopo concederetur, ut aliqua episcopalis mensae bona ${ }^{21}$ cum nobilium viciniobus $[s]$ bonis infra limites eiusdem dioecesis et mensae episcopali commodioribus permutare ${ }^{22}$ et aliqua $[k .11 \mathrm{v}] \underline{\text { etiam bona ex beneficiis quae in aliis }}^{23}$ dioecesibus obtinet et quorum retentionem propter fructuum episcopatus tenuitatem (quemadmodum et alii ipsius praedecessores) a Sede Apostolica obtinet ${ }^{24}$, sine notabili eorundem beneficiorum iactura, relicta sufficienti parte fructuum pro futuris eorundem beneficiorum possessoribus, dismembrare et vendere, ac ex precio $[s]$ illorum alia bona vicina huic mensae episcopali utiliora emere posset, procul dubio et episcopi pro tempore existentes absque tot beneficiorum retentione commodius vivere possent necessitatibusque eorum provideretur.

De quibus omnibus suprascriptis rebus sanctissimo domino nuntio supplicandum est humiliter, ita tamen ut ad confirmationem permutationis huiusmodi illustrissimis et reverendissimis dominis cardinali Radivilo, archiepiscopo Leopoliensi metropolitano ac episcopo Luceoriensi viciniori, et decano, et alteri de capitulo facultatem concedere dignetur, ut statim ac bona ipsa reperirentur, permutatio sequi posset arbitrio dictorum dominorum commissariorum neque hac de causa iterum Sedes Apostolica consulenda esset, nam cum nobilibus de permutatione frustra tractandum, nisi prius eis cautum sit, et si post tractatum ad Sedem Apostolicam mittendum esset, iam nihil fieret propter dilationem, quae omnia supplicandum est, ut arbitrio et conscienciae $[s]$ dominorum commissariorum committantur, ita ut cum evidenti utilitate ecclesiae et mensae episcopalis fiat, similiter et de unionibus suffraganeo caeterisque rebus.

In oppidis Hrubieszow, Belz et Hrodlo huius dioecesis Chelmensis sunt monasteria fratrum Ordinis Praedicatorum satis bene dotata, villas proprias habentes, in eorum quolibet unus tantum frater aut duo ad summum resident, reliquos vero proventus ${ }^{25}$ et redditus $^{26}$ dictarum villarum ad alia monasteria aliarum dioecesum ditiora et locupletiora transmittunt, hic in dioecesi propria parvam vel nullam utilitatem facientes, non satis faciendo voluntati $<$ fundatorum $>27$ eorundem monasteriorum ${ }^{28}$, qui illa pro utilitate huius dioecesis fundaverunt. Supplicandum est Sanctitati Suae, ut ex speciali gratia concedere dignetur, ut

${ }^{21}$ Korektura: wytarcie i nadpisanie.

${ }^{22}$ Fragment dopisany na marginesie: Ubi inventa fuerint bona cum evidenti utilitate mensae episcopalis illustrissimus legatus concedet licentiam, sed exprimantur bona ab utraque parte danda et recipienda eorumque valores annui et in proprietate alia necessaria specificata [?].

${ }^{23}$ Korektura: wytarcie i nadpisanie.

${ }^{24}$ Fragment dopisany na marginesie: diffido quod hoc obtineri possit etiam a Summo Pontifice ob praeiuditium [s] tot ecclesiarum et tot fundationum.

${ }^{25}$ Korektura: wytarcie i nadpisanie.

${ }^{26}$ Pierwsza litera: d przekreślona pionowa kreską.

${ }^{27}$ Stowo zapisane jako interpolacja wstawiona nad wierszem.

${ }^{28}$ Fragment dopisany na marginesie: hoc negotium a Summo Pontifice impetrari potest, dummodo omnia formentur et expediantur aperito. 
aliquod ex praedictis monasteriis cum redditibus et proventibus uberioribus ad civitatem Crasnostaviensem, ubi cathedralis ecclesia est, transferatur ibique numerus fratrum augeatur, qui cooperatores in vinea Domini reverendissimo sint, praedicationes -verbi Domininus poenitentiarii, et sacrae theologiae lectionum in ecclesia cathedrali iuxta sacri concilii Tridentini decreta obeant, quibus [k. 12] reverendissimus ecclesiam et locum residentiae commonstrabit.

Extra et prope oppidum Sokal huius dioecesis Chelmensis est ecclesia tituli Beatae Mariae Virginis in insula fluvii illius oppidi, lignea, antiqua et parva, in qua est imago devotissima gloriosissimae Virginis Mariae, multis miraculis celebris, ad quam numerosus populus devotionis causa semper confluit et est Christi fidelium in ea concursus tantus, sicut (data paritate) Loreti in Italia, nullas habet indulgentias ${ }^{29}$, supplicatur itaque pro indulgentia plenaria perpetuo duratura et remissione omnium peccatorum visitantibus dictam ecclesiam in festivitatibus et diebus gloriosissimae Virginis Mariae, cum processione cum Sanctissimo Sacramento Eucharistiae a primis vesperis etiam [?] $]^{30}$ et parochialem ecclesiam eiusdem oppidi in festo sanctorum Apostolorum Petri et Pauli, in qua die nundinae celebrantur et magnus concursus populi solet esse, similiter cum processione ut supra ${ }^{31}$.

Sunt et in hac dioecesi multae parochiales ecclesiae, in quibus propter tenuitatem fructuum et proventuum sacerdos sustentari non potest, cum et (ut supra dictum est) decimae non solvantur, supplicandum itaque est Sanctissimo Domino Nostro, ut ne supradictae parochiales ecclesiae debitis fraudentur obsequiis et ne cura animarum in eis negligatur concedere dignetur, ut loci ordinarius possit ${ }^{32}$ duas parochiales vicinas unire et eo modo deffectus huiusmodi supplebitur ${ }^{33}$.

[odcisk pieczęci, w znacznym stopniu zniszczony i nieczytelny, w ksztatcie owalnym, wys. ok. $4 \mathrm{~cm}$, szer. ok. $3 \mathrm{~cm}$, z legenda otokowa, w polu pieczęci herb Jelita, biskupa Stanistawa Gomolińskiego]

${ }^{29}$ Fragment dopisany na marginesie: petantur indulgentiae a Sanctissimo, qui concedet ad decem annos et forsan plures.

${ }^{30}$ Fragment: cum processione cum Sanctissimo Sacramento Eucharistiae a primis vesperis etiam [?] dopisany druga ręką. Zdanie zamyka nierozpoznane skrócenie, zapewne: etiam.

${ }^{31}$ Fragment: similiter cum processione ut supra dopisany druga ręka.

${ }^{32}$ Stowo przykryte częściowo odciskiem pieczęci i z tego powodu jego lekcja jest watpliwa.

${ }^{33}$ Fragment dopisany na marginesie: episcopus hoc potest facere absque alio indulto vigore facultatis sibi datae a concilio, tamen si securius agere velit, petat a Sanctissimo indultum. 